\title{
Efim Grigor'evich Etkind, 1918-1999
}

Our profession has sustained a grievous loss. Efim Grigor'evich Etkind, one of the most distinguished and vital scholars of Russian literature in our time, died after a brief illness on 22 November 1999.

Efim Etkind was born in Petrograd on 26 February 1918. He graduated in 1941 from the University of Leningrad where he specialized in Romance and Germanic philology. Among his teachers were such eminent literary scholars as V. M. Zhirmunskii, G. A. Gukovskii, V. Ia. Propp, B. M. Eikhenbaum, and B. V. Tomashevskii. In 1942 he volunteered for active duty and served with distinction in the ranks of the Red Army as an interpreter, a propagandist, and an intelligence operative. After the war he taught west European literatures, French, and German at the Leningrad Pedagogical Institute of Foreign Languages. In December 1949 when the notorious "anti-cosmopolitan" campaign was at its peak, Etkind was removed from his post and charged with "anti-patriotism." In 1952 he was invited to join the faculty of the Herzen Pedagogical Institute in Leningrad where he subsequently rose to the rank of professor, offering courses in the theory of translation, French and German literary history, stylistics, and poetics. A compelling lecturer, he soon became one of the most popular and influential teachers of literature in Leningrad.

In 1974 Etkind's stellar pedagogical career was brutally interrupted. An act of conscience-assisting Aleksandr Solzhenitsyn in preserving the Gulag Archipelago manuscripts-exacted a heavy toll. A unanimous vote of a servile Institute faculty stripped Etkind of his position and his academic degrees and blocked every avenue of publication; he stood convicted by the kangaroo court of "anti-social activities." At the same time he was expelled from the Soviet Writers' Union. (Ever since 1956 he had been a valued member of its translation branch.) Emigration, a prospect he had never contemplated, became the only option. Shortly after his arrival in France, Etkind penned an incisive and vivid account of his ordeal-Zapiski nezagovorshchika (1977)-a book which was soon translated into French, German, and English. (The title of the French version, Un dissident malgré lui is especially telling.)

While separation from the city he loved was wrenching, the new environment proved appreciative and welcoming. In 1974 he was offered a professorship of Russian literature, stylistics, and poetics at the Nanterre branch of l'Université de Paris. In 1976 Etkind was elected a corresponding member of three West German academies (Darmstadt, Mainz, and Munich). After retiring from Nanterre in 1986, his travels spanned much of the western world, and he lectured as a visiting professor in Geneva and Cologne, in Vienna and Barcelona, Norwich and Eugene, at Harvard and Yale. On both sides of the Atlantic his rare blend of eloquence and erudition won him admirers, disciples, and not infrequently junior collaborators.

The worldwide impact of Efim Etkind's teaching was inseparable from the prodigious range and richness of his scholarship. The ground-breaking Poeziia i perevod (1963) placed him among the leading Russian authorities on the theory of verse translation. His graceful and lucid Razgovor o stikhakh (1970) reached toward the general reader only to be followed several years later by the magisterial Materiia stikha. Completed before his forced emigration, this book was turned down by the publisher "Sovetskii pisatel" on the grounds that it "assigned to poetry an absolute value, irrespective of its social mission." Published twice in the west $(1978,1982)$, Materiia stikha was recognized as a major contribution to structural poetics. (Though profoundly indebted to the formalist-structuralist tradition, its author tended to steer clear of doctrinal commitments. He once described his methodology half seriously as "structuralism with a human face.")

Steeped as he was in west European literatures, Etkind was ideally suited for the role of a cultural intermediary and a bridge builder. His own impeccable scholarship meshed seamlessly with projects that he launched or masterminded, such as a new edition of Aleksandr Pushkin in French (1982) that earned him a special prize from Académie Française 
or the two-volume collective Histoire de la littérature russe $(1987,1990)$. In 1986, he was awarded the title of Chevalier de Palmes Académiques in recognition of invaluable services rendered to French education.

The flow of publication continued unabated until the fall of 1999 when the killer disease closed in on Etkind. In fact, the last decade of his life, framed by two studies on Pushkin - Simmetricheskie kompozitsii u Pushkina (1988) and Bozhestvennyi glagol (1999)proved especially fertile. Tam, vnutri. O russkoi poezii XX veka: Ocherki (1996), a large canvas that ranges from Aleksandr Blok to Nikolai Zabolotskii, grew out of a lifelong love affair with its subject. In this "inside" view, careful and incisive analysis is inseparable from an affectionate immersion in the textures, the rhythms, the epiphanies of modern Russian poetry. "Vnutrennii chelovek" $i$ vneshniaia rech' (1998) is a pioneering venture into "psychopoetics," where close readings of Russian artistic prose of the eighteenth and nineteenth centuries provide a new perspective on the relationship between style and psychic reality, exploring the manifold fictional modes of revealing or "verbalizing" the inner self.

Toward the end of his life, Etkind reverted to, and came to terms with, his roots by rendering into Russian one of the most powerful poetic responses to the Holocaust. His masterly translation of Itzhak Katzenelson's Yiddish epic poem Skazanie ob istreblennom evreiskom narode is scheduled for publication in Moscow in the course of this year.

All of us who had the good fortune to know Efim Etkind personally can testify that the intensity of his dedication to literary scholarship was matched by his zest for life and his gift for friendship. As one who for thirty years was a beneficiary of this gift I find it exceedingly hard to come to terms with the notion that a man as vital, as marked by seemingly inexhaustible mental and physical energy as Efim Etkind is no longer among us. Even as I mourn the passing of an irreplaceable friend and soul mate, I salute the memory of a life fueled by an unswerving commitment to Russian and European culture, a life keenly and lovingly attuned to the literary imagination.

VICTOR ERLICH

Yale University

April 2000 